\title{
Regilaul on samuti eesti luule Küsimusi Ruth Mirovile 75. sünnipäeva puhul
}

\author{
Karin Maria Rooleid
}

\begin{abstract}
Millal tajusid esmakordselt eesti rahva ja luule olemasolu? Oli see varajane ärkamine lapse- ja koolipõlves või lähenesid rahva tundmisele hiljukesi samm-sammult oma varasema elukogemuse ja kirjanduse kaudu? Või oli see lihtsalt üks suur juhus ja saatuse sattumine?
\end{abstract}

Pärimuslik, suuline kultuur ümbritseb meid kõikjal. Minul, nagu ehk enamikul minuaegsetel ja nüüdsetel lastel, algas rahvaluulest osasaamine muinasjuttude lugemise või ettelugemisega, niisiis juba kirjakultuuri kaudu. Traditsioonilisi pühi, eriti jõule ja lihavõtteid, on meie peres aga alati peetud, ka siis, kui need nõukogude ajal keelatud olid.

Meie pere kolis 1937. aastal Viljandist Nõmmele. Samal aastal hakkasin õppima Kivimäe algkooli teises klassis. Mäletan, et suurel vahetunnil ja pidude ajal mängisime koolis alati ringmänge. Nõmme laste sõpruskonnas osati üldse tohutult mänge, sealhul-

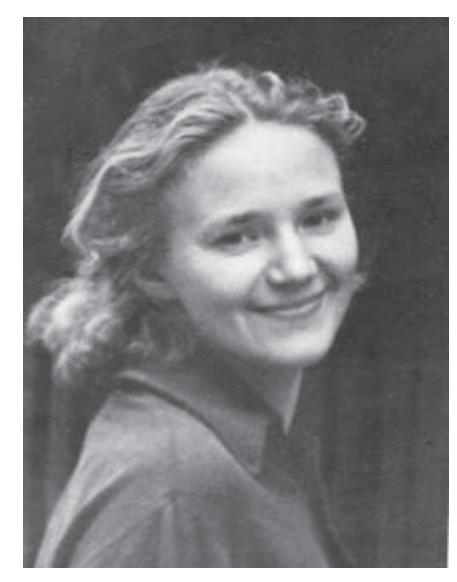

Foto 1. Ruth Mirov 1951. aastal Foto erakogust.

gas palju pärimuslikke. Neid mänge ei õpetanud meile vanemad inimesed ega õpetajad, vaid nende oskamine tuli kuidagi iseenesest. Ühiselt käisime ka mardi- ja kadrisandiks. Minu põhjalikum kokkupuude rahvaliku laulu ja pillimänguga toimus sõjaajal ja esimestel sõjajärgsetel aastatel maal. Et linnas oli sel ajal toiduga äärmiselt kehv, saadeti lapsed suveks maale kosuma. Mina olin suviti kostil isa kolme venna ja viie õe taludes, mis asusid Jõhvi ümbruses. Arusaadavalt tuli maal tööd teha - käsi- või hoburehaga heina riisuda ja rukkivihke siduda. Koos täditütardega käisime ka koha- 
likel pidudel - simmanitel, kus mängiti ringmänge, lauldi ja tantsiti. Selle aja peamine pill oli akordion ja pillimehed olid väga hinnatud. Kui kellegi kohta öeldi üle küla pillimees, kõlas see justkui aadlitiitel.

Tegeliku või ametliku teadmise kirjandusest ja rahvaluulest sain kooliõpetuse kaudu. Õppisin Nõmme Gümnaasiumis selle kooli hiilgeajal, aastatel 1942-1947. Meie klass oli täis loovaid andeid. Sealt tulid Eesti kultuurilukku bioloogid Erast Parmasto ja Hans Trass, keeleteadlane Valmen Hallap ning lavastaja-näitleja Kulno Süvalep. Koolis tegutses humanitaarring, mida juhatasid eesti keele õpetajad Nikolai Remmel ja Marta Sillaots. Nemad õpetasid meid kirjanduse ja kirjandite kirjutamise kaudu iseseisvalt mõtlema. Suurt austust äratasid minus Nõmme Gümnaasiumi direktorid Alfred Teaste ja Nikolai Remmel. Mõlemad olid suurepärased kasvatajad ja õpetajad, ja mõlemad represseeriti hiljem nõukogude võimu poolt: A. Teaste mõisteti kümneks aastaks vangilaagrisse, sest ta olevat noori valesti kasvatanud, N. Remmelil keelati hiljem üldse õpetajana töötamine. Ka Marta Sillaots saadeti kümneks aastaks Siberisse.

Kooli ajal kirjutasin ma võrdlemisi häid kirjandeid ja joonistasin meeleldi. Minu tegelikuks unistuseks oligi õppida mõnd kunstiala, kuid ma ei julgenud end kunstiinstituuti pakkuda - sinna oli juba tol ajal raske pääseda ja ma ei olnud enda andes nii kindel. Läksin 1947. aasta suvel hoopis lastelaagrisse kasvatajaks. Siis tuli sügis ja ärkamine - kõik sõbrad olid kuhugi õppima läinud, mina aga olin tuultele valla. Tekkis mõte minna toitlustehnikumi, kus õpetati tulevasi dieetõdesid ning toiduainetetööstuse ja toitlusasutuste keskastme juhte. Aasta pärast, 1948. aastal suunati mind praktikale Kalevi kommivabrikusse. Mulle see suure vabriku õhkkond ja imal karamellilõhn ei passinud. Teise poole praktikast sooritasin väikeses pagaritööstuses, mis asus Pühavaimu kiriku vastas, endise Stude maiustustepoe ruumides. Stude äri mäletasin ma lapsepõlvest, ja näis nagu oleks aeg siin peatunud. Töökoja sisustus oli pärit Stude ajast, kondiitrid ja martsipanimeistrid olid kõik eesti ajal välja õppinud mehed, kes teadsid veel, mida tähendab ametiau. Martsipanimaalijate seltskond oli väike ja vaimukas, õhkkond meeldiv ja asjalik, töö omal kombel loov. Kui siis teada sain, et järgmisel aastal suunatakse mind tööle Kalevisse, jätsin tehnikumi pooleli ja hakkasin Studes martsipanimaalijaks. Sinna ma kauaks ei jäänud. 1949. aastal abiellusin oma koolikaaslase, paralleelklassi poisi Boris Miroviga, novemb- 


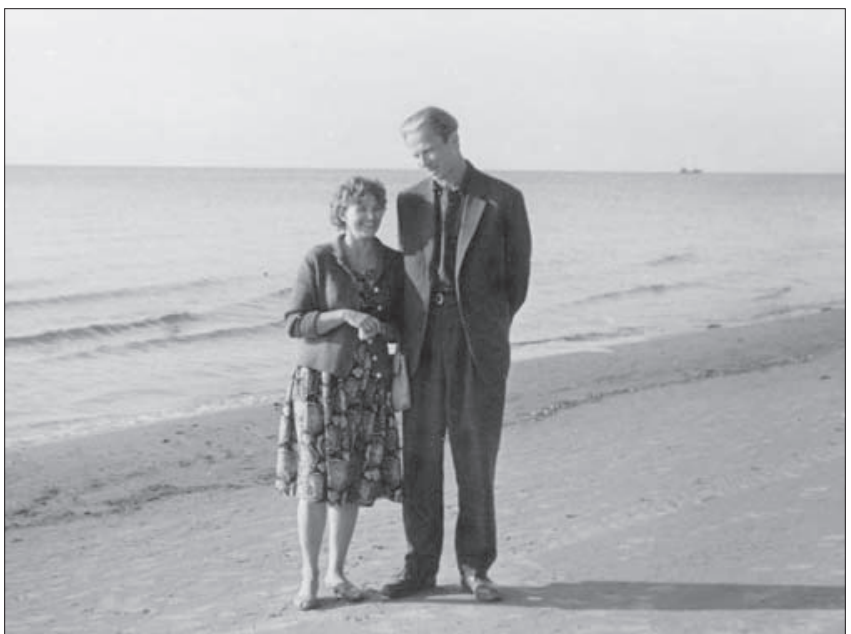

Foto 2. Ruth ja Boris Mirov Narva-Jõesuus 1960. aastatel. Foto erakogust.

ris 1950 sündis esimene tütar Krista ja minul tuli 1951 töölt koju jääda. Ajad olid rasked ja vaevalised. Töötasin veidike riikliku raamatukogu (praeguse Eesti Rahvusraamatukogu eelkäija) komplekteerimisosakonnas, 1952. aastal olin eesti keele ja joonistamise õpetaja Rahumäel 27. mittetäielikus keskkoolis. Pärast teise tütre Mare sündi 1952. aasta augustis jäin kuni 1956. aastani koju.

Oled pereinimene ja ema. Kui suur osa sinu elust kuulub jäädavasti abikaasa Boris Mirovile? Kui suur osa kuulub sinu kahele tütrele, sinu kuuele lapselapsele, sinu lapselapselapsele? Eesti arhitektuurile?

Borisiga tutvusin Nõmme Gümnaasiumis. Nende pere oli tulnud Nõmmele Tartust sõjapõgenikena. Minu abikaasa isa Boris Mirov oli pidanud Tartus farmatseudiametit ja olnud tegev korporatsioonis Fratenitas Liviensis. Tallinnas töötas ta apteekide peavalitsuse keskapteegilaos. 1948. aastal, kaks päeva enne jõule ta arreteeriti ja viidi Pagari tänavale ülekuulamisele. Talle esitati selle aja kohta nii tavalised absurdsed süüdistused ja saadeti edasi Moskvasse Ljubjankale, sealt kümneks aastaks Siberisse Taišeti vangilaagrisse. Borisi isa vangistus märgistas ühtlasi kõik sugulased Eestis olime rahvavaenlased. Boris õppis sel ajal Tallinna Polütehnilises 
MEIST ENDIST

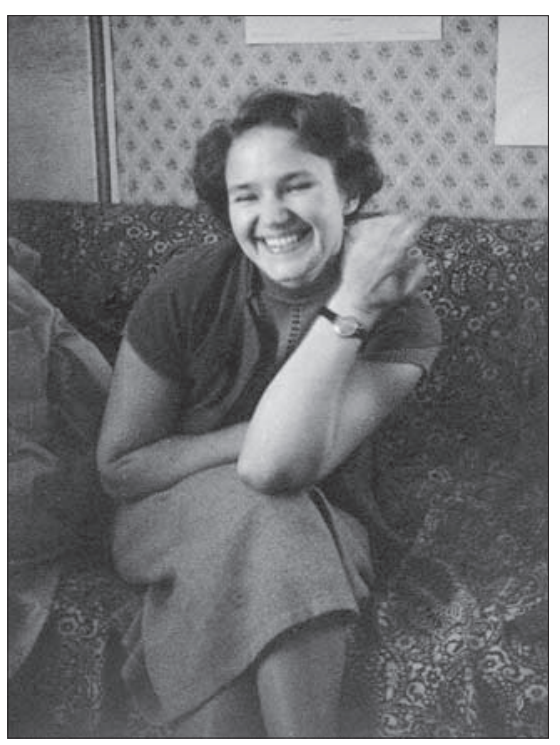

Foto 3. Ruth Mirov 1956. aastal. Foto erakogust.
Karin Maria Rooleid

Instituudis arhitektuurija tundis pidevat hirmu, sest instituudis toimusid samuti arreteerimised, sealt otsiti neid poisse, kes olid teeninud Saksa sõjaväes. Meheema sel ajal tööd ei leidnud. Mõnda aega olin mina martsipanimaalijana peres ainuke, kes palka sai. Lõpuks, 1951. aastal sai meheema tööle - ta võeti raudtee polikliinikusse hambaravi osakonda koristajaks. Raudteeametis töötasid peamiselt venelased ja juudid, kes eesti keelt ei osanud. Meheema oskas aga hiilgavalt vene keelt, sest oli omal ajal lõpetanud Tartus Puškini Gümnaasiumi.

Pärast Stalini surma alanud üldise rehabiliteerimise käigus vabanes ka Borisi isa. Koju pääses ta 1956. aastal, tema ees vabandati eksituse pärast, ennistati endisele töökohale ja talle maksti "kompensatsiooniks" kahe kuu palk. Vahepealsete aastate jooksul olid mõlemad pojad naise võtnud, meil oli kaks last, aga elasime kõik ikka veel sellessamas väikeses korteris, mille Borisi pere sõjapõgenikena tulles oli Nõmmele saanud. Kuigi olime sõbralik pere, oli selge, et nii tihedalt kaua koos elada ei saa. Et meid korterijärjekorda ei võetud, pidime otsima muid võimalusi. Õnneks oli üks minu tädidest juba eesti ajal Nõmmele krundi ostnud. Nüüd saime taotleda ehitusloa 600 ruutmeetri peale sellest tädi maatükist. Kui 1958. aastal ehitama hakkasime, töötas Boris Eesti Maaehitusprojektis arhitektina, kuid meil ei olnud pennigi hinge taga. Sellepärast pidime kõik lihtsamad ehitustööd, alates maja vundamendi valamisest kuni soojustuse paigaldamiseni, tegema ise. Noorele arhitektile oli see muidugi huvitav väljakutse, mina olin ehitusel rohkem abitööline. Teatavasti olid sel ajal ka laupäevad tööpäevad, ja nii saime ehituseks kasutada vaid pühapäevi ja puhkust. Ajale iseloomulik nali oli seegi, et linna ametkond nõudis maja valmimist mingiks määratud tähtajaks. Nii kiiresti me ehitada muidugi ei 
suutnud ja seepärast pidime mitu korda pikendust paluma. Seitse aastat ehitasime oma väikest majakest.

Nüüd olen ligi seitse aastat lesk olnud. Kui mõtlen tagasi kooselatud aastatele, võin öelda, et kasvasime abikaasaga kokku õnnes ja õnnetuses, heades ja halbades päevades. Loomult olime kaunis erinevad: tema oli vaieldamatult tark ja andekas, vaimukas ja avatud seltskonnainimene, mina rohkem omaette olija ja vähese jutuga. Et Borisil oli omajagu enesekindlust ja tervet auahnust, edenes ta oma erialal hästi, sai lõpuks Maaehitusprojekti peaarhitektiks ja õpetas Kunstiinstituudis arhitektuuri. Parteisse ta ei astunudki, kuigi survet avaldati. Ta oli ka väga avameelne ja ütles sageli välja asju seal, kus enamik oleks end tagasi hoidnud. Välismaalgi käis ta ainult paaril korral, sest ei tahtnud teha tegemist nende ametitega, kust tuli sõiduks luba taotleda. Ajalugu ja geograafia olid tema huvialad ja neis olid tal väga suured teadmised. Vanemas eas tekkis abikaasal veel kaks harrastust - autoga reisimine ja jahiga purjetamine. Autoga sõitsime läbi terve Eesti ja selle lähiümbruse, kusjuures Boris oli tänu laialdastele arhitektuuriajaloolistele teadmistele meile alati heaks teejuhiks. Temalt õppisin maailma nägema "arhitekti pilguga”. Praegugi, kui tänavatel käin, vaatan maju alati selle pilguga... Kurb ainult, et kõrval ei kõnni enam see, kellega neid muljeid jagada.

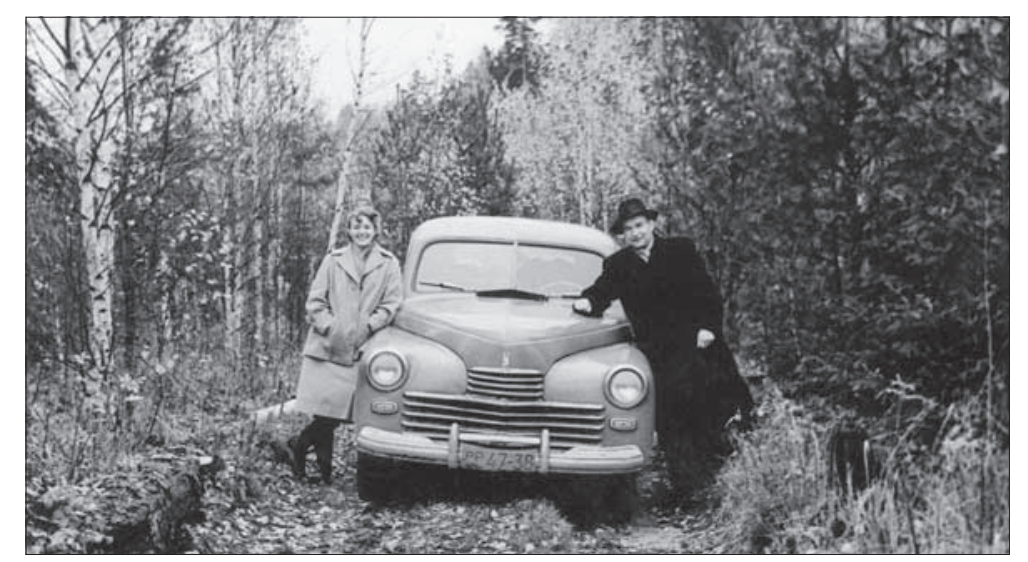

Foto 4. Ruth Mirov koos Richard Viidalepaga1958. aastal Kuremäel Kalevipoja pruuti otsimas. Foto erakogust. 


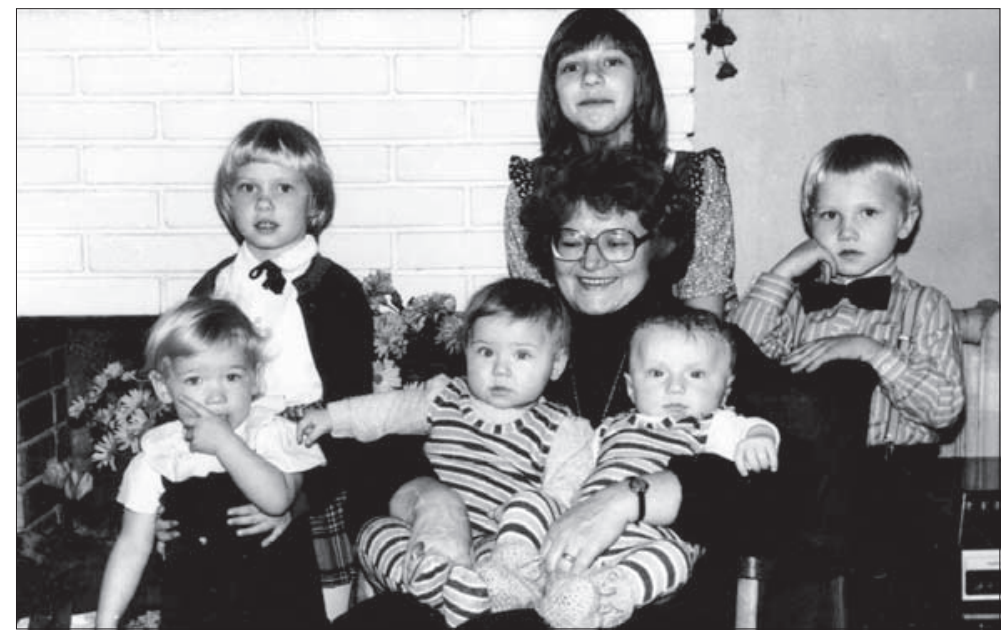

Foto 5. Ruth Mirov lapselastega 1983. aastal. Foto erakogust.

Mulle on suureks toeks, et tütretütar Piret praegu elab minu juures, nii saan end ikka veel tunda harjumuspärases pereema rollis. Minu lapselapselaps Robin sai hiljuti aastaseks. Ta on väga elav ja energiline poiss. Need vähesed päevad, mis olen saanud koos temaga veeta, on värskendavad - nagu võimlemistunnid hommikust õhtuni.

Kuidas jõudsid Eesti rahvaluuleteadusesse? Mäletad ehk oma esimesi folkloristlikke väljakutseid ja ülesandeid? Esimesi nõuandjaid ja abistajaid? Esimesi õnnestumisi?

Keele ja Kirjanduse Instituuti sain tööle 1956. aastal, esialgu murdesektorisse mittekoosseisulise sedeldajana. 1957. aastal avanes võimalus saada laborandi koht rahvaluulesektoris, kus juhatajaks oli Richard Viidalepp. Järgmisel aastal võttis R. Viidalepp mind kaasa Kirde-Eestisse Kuremäele Kalevipoja muistendeid koguma ning tema tööd vaadates ja kuulates saingi oma esimesed teadmised rahvaluule kogumisest.

Rahvaluulesektoris sattusin kohe eesti rahvalaulude antoloogia koostamise juurde. Seda tööd tegime peamiselt koos Veera Pino ja Ülo Tedrega, kes oli ühtlasi rühma juht. Töö oli aeganõudev ja vaevarikas. Rahvalaulutekstid pidime ise Tartu arhiivist välja otsima ja suure osa neist tekstidest ka ise käsitsi kopeeri- 
ma, sest sel ajal ei olnud võimalust kasutada masinakirjakoopiaid ega mikrofilme. Minule oli see töö väga oluline ja arendav, sest alles selle käigus õppisin tundma ja kõrgelt hindama regilaulu. Üsna kiiresti kodunesin ka laulude tüpologiseerimisega ja minust kujunes veendunud "tüpoloog". Olen tänini seisukohal, et ilma tüpoloogiata ei suudaks me eesti regilaulustikus üldse orienteeruda.

Nüüd tahan rääkida sellestki, kuidas minust sai ametlikult rahvaluuleteadlane. 1950. aastate lõpul hakkasin Tartu Ülikoolis eesti keelt ja kirjandust õppima. Õppisin kaugõppes, või nagu siis öeldi, mittestatsionaarselt. Pere kõrvalt õppimine edenes muidugi visalt. Hinded olid mul küll korralikud, kuid igal sessioonil jäi midagi tegemata ja hinges kripeldama. Kolmanda kursuse lõpul ma enam nii ei jaksanud ja läksin lahkumisjutuga ülikooli kaugõppeprorektori Julius Adojaani juurde. Dotsent J. Adojaan ütles mulle heatahtlikult: Ärge minge ära, leiame mingi põhjenduse. Aga mina läksin siiski. Mõni aasta hiljem, kui lapsed juba suuremad olid, tahtsin jätkata õppimist tookordses Tallinna Pedagoogilises Instituudis. Läksin 1965. aastal Kõrgema ja Keskerihariduse Komitee esimehe Madis Pesti jutule, kelle nõuannete järgi asusin korraldama enda üleviimist Tartust Tallinna. See asjaajamine osutus üsna keeruliseks. Kõigepealt pidin end Tartu Ülikoolis üliõpilaseks "taastama" ja sooritama vähemalt ühe eksami, siis alles tekkis võimalus Tallinna Pedagoogilises Instituudis immatrikuleeruda. Õpinguid tuli alustada teiselt kursuselt. Tundub, et tollases instituudis oli mõne aine õpetus isegi tugevam kui ülikooli kaugõppijatele. Näiteks luges siin eesti kirjandust Richard Alekõrs, kes oli omal ajal Keele ja Kirjanduse Instituudi (KKI) teaduri kohalt ebaõiglaselt lahti lastud. Tema sisukat Tõe ja õiguse analüüsi mäletan tänini.

Pärast kõrgkoolidiplomi omandamist 1969. aastal lootsin salamisi, et saan nüüd töökohaski teaduriks, kuid mulle anti nooremteaduri koht alles 1971. aastal. Sel ajal tundsin tõesti, et ma ei maksa maastki rohtu ega sünni suurte sekka.

Rahvaluules huvitas mind kõige enam regilaul, kuid selles vallas mul mingeid erilisi väljavaateid polnud. Regilaulu uurimisala oli tol ajal tihedalt uurijatega kaetud, alates sellistest nimedest nagu Herbert Tampere, Eduard Laugaste, Ülo Tedre, Veera Pino ja Olli (Olga-Ottilie) Kõiva. Nii saigi minu uurimisteemaks regilaulu ääreala - vanemad laulumängud. Selle teema 
soovitas mul võtta Richard Viidalepp, kes oli omal ajal samuti mängude uurimisega tegelnud.

Tartu Ülikooli magistri- ja doktorikraadi omandasid sa alles möödunud kümnendil. Eepose-igatsus (1993) ja Regivärsilise ekspositsioonlauluga voormängud (1999) on tõhusad ja küpsed lugemised. Miks oli sinu tee nende kaitsmiseni siiski nii pikk ja käänuline?

Vanemad laulumängud oli minu ametlik uurimisteema ja minu kohus olnuks see tunduvalt varem kandidaaditööna valmis kirjutada ja kaitsta. Aga eelnevast selgub, et olin kaunikesti killustatud. Tööl oli pealegi teisi ülesandeid, nagu bibliograafiate ja kartoteekide koostamine jms. Ka sai mõnda aega rahvaluulealaseid töid kaitsta ainult Moskvas, Leningradis või Kiievis ja töö pidi olema vene keeles. See kõik ei inspireerinud. Muidugi, 1980. aastate lõpus sai küll jälle ka Keele ja Kirjanduse Instituudis kaitsta. Ma ei hakka siinkohal pikemalt seletama, ütlen vaid, et ma ei kasutanud ega tahtnudki kasutada seda võimalust.

Suured asjad nõuavad aega keskendumiseks. Hoopis lihtsam on kirjutada väikseid asju parasjagu huvitaval teemal. Vajasin sellist kirjutamist tõestamaks ennekõike iseendale, et ma pole päris võimetu. Luule- ja muid retsensioone kirjutades pidasin ikka silmas folkloristlikke aspekte ja nii hakkas kooruma midagi kompaktsemat kirjanduse ja rahvaluule suhete vallas. See teema mul ametlikus plaanis polnud ja enamiku asju kirjutasingi vabast ajast, kodus. Nii et puhtal kujul hobby. Eesti Vabariigi ajal kehtestati uued kaitsmistingimused ja selgus, et kraadi saab taotleda ka ilmunud artiklite põhjal. Neid mul oli. Kaitsmise mõtet toetas Ülo Tedre, kes nõustus olema ka üheks oponendiks, teine oli Ants Järv. Kaitsmine läks korda. See toimus teadusnõukogu saalis Tartu Ülikooli rektoreid kujutavate maalide all. Oli ülev tunne - ometi sain ühe oma uurimisteemadest ümmarguse lõpuni viidud. Veidi hiljem, 1996. aastal õnnestus kaitsmisele esitatud kokkuvõte ajakirjas Akadeemia ka avaldada. Mõned, nende hulgas minu abikaasa, arvasid kaitsmise ajal, et ma väärinuks doktorikraadi, kuid siis tulnuks kogu protseduuri uuesti alustada. Pealegi olin mina ise magistrikraadiga ülimalt rahul. Midagi hakkas kripeldama hoopis hiljem, kui magistrikraadi väärtus aina vähenes ja vähenes. 
Niisiis, ühele teemale õnnestus magistrikraadiga punkt panna, aga minu teine, plaaniline teema Laulumängud rippus ikka veel õhus. Sundisin ennast unustusse vajunud asju uuesti kätte võtma ja kirjutasin ühe peatüki varem valminud osadele lisaks. Et Regivärsilise ekspositsioonlauluga voormängud (1998) üldse raamatuks sai, selle eest võlgnen suure tänu oma noorele kolleegile Karin Maria Rooleidile. Tema küljendas ja kiletas teksti hoolikalt ja täpselt, nagu kõik muugi, mida ta teeb. See oli üks tema esimesi sedalaadi töid. Aga mina solkisin asja ära, tehes viimasel hetkel tekstis mingi paranduse, mis lõi mõned järgnevad sõnapoolitused sassi. Märkasin seda trükitud raamatus mõni päev enne kaitsmist ja jahmusin hirmsasti. Helistasin Tartusse õppetooli ja ütlesin, et jätame kaitsmise ära. Nad naersid ja arvasid, et ega nad nii väiklased ka ole.

Kaitstud sai seegi töö, kuid olin hirmsasti närvis. Isegi vanadus pole parandanud minu paanilist hirmu avalike esinemiste ees. Selline seisund ei ole mõistusega kontrollitav ja seekord oli asi eriti hull - midagi ma rääkisin, aga ma ei mäleta, mida. Sama tunne oli mul siis, kui tegin kunagi kandidaadimiinimumi erialaeksamit. Nooremana püüdsin sellest hirmutundest üle saada, sundides ennast ettekandeid pidama, vananedes võtsin teise taktika - esinemiste vältimise. Nagu eelmisel, nii olid ka kõnealusel kaitsmisel kõik väga heatahtlikud, nii oponendid Tiiu Jaago ja Luule Epner kui ka sõnavõtjad publiku hulgast - Ingrid Rüütel, Arvo Krikmann ja teised.

Doktoridiplom anti kätte sügistalvisel Tartu Ülikooli pidulikul aktusel. Õhtusel koosviibimisel oli palju tuttavaid. Südant jäid soojendama Eduard Vääri öeldud sõnad: Pole oluline, millal, peaasi, et tegu on tehtud. Ise arvan umbes sama. Kraadid on muidugi kenad asjad, aga minu enesetundele oli palju olulisem, et sain oma pikaajalisele ja sealjuures ametlikule teemale punkti pandud.

Omas mõttes ja meeles pean oma magistritööd tugevamaks kui doktoritööd. Olen ikka püüdnud näidata ja osutada, kui tihedad on meie ilukirjandusliku luule ja regilaulu seosed. Aga mulle tundub, see ei ole pärale jõudnud ega kõlapinda leidnud. Ometi on regilaul meie luule ürgläte ja paljud regivärsijooned, nagu alliteratsioon ja mitmesuguse kordusalusega poeetikavõtted, on eesti luules lausa orgaanilised. Kui omal ajal Jakob Hurt ja hiljem nooreestlased hindasid regilaulu peamiselt luulena, siis nüüd on mindud teise äärmusse, hinnatakse ainult laulu esitust, ka originaalist ükskõik kui kaugele minevat viisitöötlust, sõnade ilu ja sisurikkus jääb nagu tagaplaanile. Ometi on regilaulus sõnad esma- 


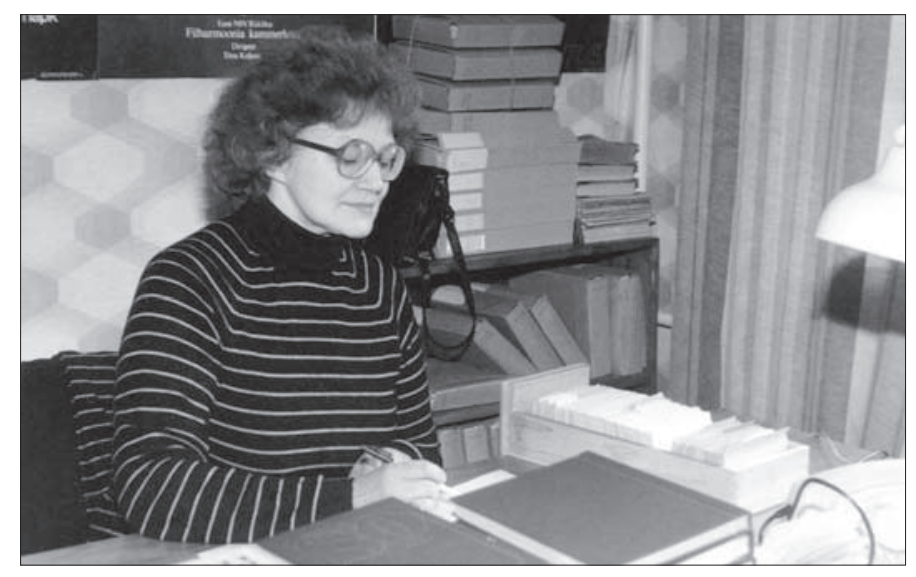

Foto 6. Ruth Mirov 1987.aastal oma töökohal Keele ja Kirjanduse Instituudis. Foto erakogust.

tähtsad. Tahan öelda, et regilaulu võiks ikka ja alati vaadelda ka kui luulet. Soovisin seda "luulesõnumit" häälekamalt kuulutada, panin kokku oma magistriväitekirja aluseks olnud kirjutised ja lisasin mõned uued samateemalised. Tänu Krista Aru, Mare Kõiva ja Toomas Väljataga toetusele sai sellest käsikirjast raamat pealkirjaga Sõnast sõnasse (2002). Vaevalt mu sõnum kuhugi eriti kuuldus, aga vähemalt välimuselt on raamat ilus ja minul endal sellest suur rõõm.

Tööalaste asjade kokkuvõtteks ütlen, et kui ma ikka tõsimeeli ja kogu südamest midagi olen ette võtnud, olen alati leidnud heatahtlikke ja mõistvaid toetajaid, kes sõna ja teoga on aidanud edasi liikuda.

\section{Üheks sinu ideaalkujuks ja paleuseks on jätkuvasti ja küllap igavesti Jakob Hurt. Sa oled välja andnud väga kauni raama- tu tema nelja Vana Kandle keelest ja üllitanud mitmed J. Hurda elu valgustavad kirjutised. Kuidas sa temani jõudsid?}

Jakob Hurt on usutavasti kõigi folkloristide ideaalkuju. Teisiti nagu ei saakski temasse suhtuda. Kui J. Hurt ei oleks lausa viimasel hetkel rahvaluule suurkogumist algatanud, paljukest meil siis üldse oleks regilaulu üleskirjutusi. Jääks peamiselt setu, aga setu regilaulgi on oma puhtamal kujul Jakob Hurda ajal kirja pandud. Regilaul on kahtlemata üks meie suurimaid kultuuriväärtusi, mille võime uhkelt paigutada ükskõik missuguse teise rahva ükskõik 
kui vana sõnalise kultuurisaavutuse kõrvale. Olen palju lugenud J. Hurda kirjutusi ja tema kohta kirjutatut. Sügavat austust väärib see, et ta ei kaotanud kunagi silmist suuri rahvuslikke eesmärke, ükskõik kui solvatuna ta end isiklikult tundis. Kui J. Hurda algatatud ja hästi funktsioneerima pandud rahvuslikud suurettevõtmised tema käest ära võeti, leidis ta ometi võimaluse püstitada väikesele, erimeelsustest lõhestatud eesti rahvale igavene monument rahvaluulekogude kujul. Tunnen alati sügavat nördimust, kui mõnes teatmeteoses märkan, et teda jälle halvustavalt klerikaaliks või tagurliku klerikaalse suuna esindajaks on nimetatud. Minu silmis on Jakob Hurt inimene, kes läbi aegade meie rahvajuhtide hulgas kõige suuremat austust väärib.

\section{Oled koostanud August Annisti bibliograafia ja käsitlenud sügavuti tema tõlke- ja luuleloomet. Sina ja August Annist?}

Ka August Annist on omal kombel meie rahva suurkuju. Nagu Jakob Hurta, nii iseloomustab ka A. Annistit tohutu töövõime, samuti töö tulemuslikkus. Ilma A. Annistita ei oleks meil maailma tähtsamate eeposte Kalevala (1939; 1958), Iliase (1960) ja Odüsseia (1963) tõlkeid ega sellist Kalevala ja Kalevipoja uurimust. Kui ma tema enda eepost, eriti selle viimast osa retsenseerisin ning tema noorepõlveesseid ja luuletusi lugesin, mõistsin, et mingis mõttes oli ta Jakob Hurda püüdluste jätkaja. Ka tema tahtis oma väikest rahvast vaimselt ja füüsiliselt paremaks kasvatada ning püsimajäämiseks vajalikku üksmeelt sisendada. Kui ma seda kõike mõistsin, ei olnud August Annistit enam meie hulgas.

Temast on mul siiani meeles niisugune pilt. Insuldi tagajärjel oli A. Annisti liikumine raskendatud ja tema üks käsi halvatud. Alati, kui ta kuhugi istuma jäi, masseeris ta oma terve käega haiget, püüdes nagu sellesse elu tagasi tuua. See võitlus, see omamoodi lootus ja lootusetus, see oli liigutav. Ja palju töid oli tal veel pooleli, ja mõtteid tulvas temalt endiselt.

Kirjanduse ja rahvaluule suhete aspektist oled vaadelnud mitme eesti poeedi regivärsisugemeid. Kuidas leidsid tee Hella Wuolijoe, Villem Grünthal-Ridala, Johannes Aaviku, Betti Alveri ja Hando Runneli loomeni?

Hella Wuolijoe Sõja laulu peale sattusin juhuslikult, raamatuke lihtsalt torkas kusagil silma. Ja kuna "Venna sõjalugu" on meie 
regivärsilises lüroeepikas üks kunstiküpsemaid, siis tärkas huvi ka poeemi vastu. Õnnelikke leide oli muidki, õigupoolest sattusid kõik H. Wuolijoe tõlked soome, saksa ja vene keelde minu kätte õnnelike juhuste tõttu. Venekeelse tõlke näiteks leidsin Teaduste Akadeemia arhiivist midagi hoopis muud otsides. Asja üdi ongi õieti neis tõlgetes, mis näitab, et keerulise ja sündmusterohke elukäiguga maailmakuulsal draamakirjanikul püsis kodumaa rahvalaul ja selle põhjal sündinud väike poeem kogu elu meeles ning ta üritas korduvalt seda laiemalt tutvustada.

Sõja lauluga seoses on mul meeles paar veidrat lugu. Algul, kui mul oli ainult kaudne teadmine, et $\mathrm{H}$. Wuolijoki on poeemi aluseks olevatest regilauludest koostanud ka mingi registri (hiljem sain registrist isegi koopia, mille hankis üks Soome tuttav sealsest riigiarhiivist), kirjutasin artikli, kus võrdlesin poeemi teksti rahvalaulust pärinevate motiividega. Kuna parasjagu muud kohta avaldamiseks ei leidunud, andsin selle Teaduste Akadeemia Toimetistele, kus artikkel ilmuski. Aga, oh imet, artikli pealkirja peal oli minu nimi, aga selle alla kirjutatud: esitanud $E$. Sõgel. On küll arusaadav, et toimetuses ei leidunud kõigi akadeemia egiidi all viljeldavate erialade esindajaid ja oli vaja vastutavat isikut, aga selline vormistus! Kirjutasin toimetusele protestikirja. Vaevalt minu tühine kiri midagi luges, aga varsti selline vorm akadeemilisest väljaandest siiski kadus.

Teine veider lugu oli järgmine. Soomes ilmus sel ajal Pekka Lounela raamat Hella Wuolijoki - legenda ja eläessään (1979) ja ma palusin see raamat mulle võimaluse korral saata. Saingi suure, aga väga kõhna ümbriku, mille sees oli ainult üks õhuke brošüürike. Lähemalt uurides selgus, et postist on eemaldatud üks Nõukogude Liidus keelatud raamat. Nali missugune - kommunistlike vaadetega Hella Wuolijoe elulugu oli Nõukogude Liidus keelatud! Raamatu ma siiski sain. Kari Laukkanenis tekitas juhtum niisugust pahameelt, et ta tõi mulle uue eksemplari oma kohvris muude raamatute hulgas.

Villem Grünthal-Ridala ja Johannes Aavik olid teatavasti koolikaaslased Kuressaare gümnaasiumis, tegutsesid koos sealse koolinoorte ajakirja toimetamisel ja õppisid omaalgatuslikult võõrkeeli. Hiljem sidus neid kuulumine Noor-Eesti rühmitusse ja mitmed juhtumid ärevatel aegadel 1905. aasta paiku. Kuigi pärastpoole nende vaated ja eluteed lahknesid, iseloomustas mõlemat sügav rahvuslik meelsus ja lugupidamine meie regilaulust. Siit lähtus ka minu huvi mõlema kirjamehe vastu. 


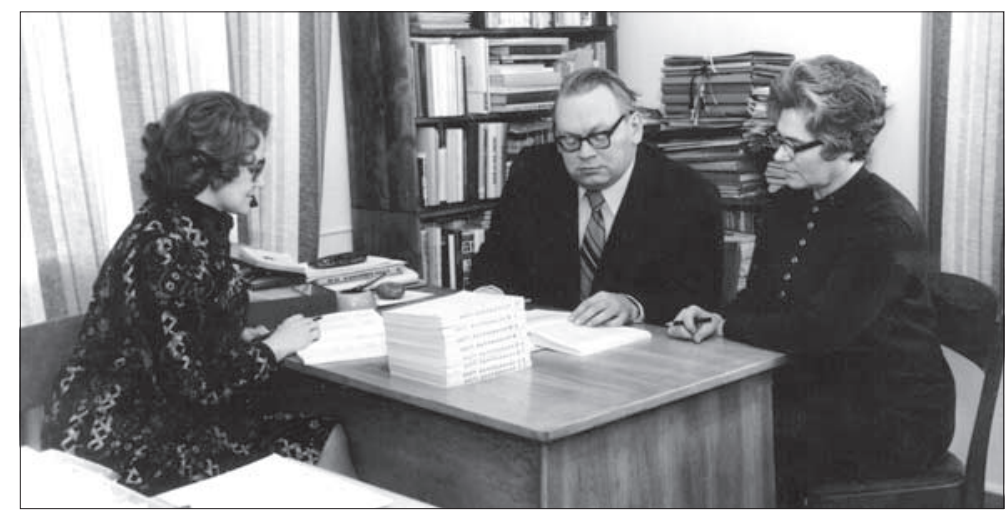

Foto 7. Ruth Mirov, Ülo Tedre ja Veera Pino Keele ja Kirjanduse Instituudis 1977. aastal. Foto erakogust.

Kirjutades väikest uurimust V. Ridala poeemist Toomas ja Mai lugesin muudki temaga seotud kirjasõna ja sattusin vihjele poeemi Püha Rist olemasolust. Poeem jutustab Jeesuse elust kõigi nelja kanoonilise evangeeliumi põhjal ja on kirjutatud regivärsivormis. Kui mina poeemi jälgi ajama hakkasin, oli juba Eesti Vabariigi algus ja tegutses selline eestlasi toetav organisatsioon nagu Viro Säätiö. Selle esindajaks Eestis oli Mart Meri, tookord ühtlasi Emakeele Seltsi sekretär. Et seltsi ruumid asusid meie rahvaluulesektoriga samal korrusel, oli lihtne täita nõutavaid rahataotluse pabereid. Saingi Viro Säätiölt väikese toetuse ja sõitsin Soome V. Ridala käsikirjaga tutvuma. Olin eelnevalt välja selgitanud, et käsikiri on perekonna valduses Hyvinkääl. Villem Ridala pojal Veljo Grünthalil oli väga hea meel, et keegi tema isa loomingu vastu huvi tunneb. Ta lasi kopeerida poeemi 1455 lehekülge ja lähetas selle postiga Tallinna. Sain Hyvinkääl uurida ka V. Ridala enda märkmeid poeemi kohta ja Helsingi ülikoolis tema loengute ja õppeplaanide pabereid. See kõik oli väga valgustav ja avastuslik.

Poeemi lugedes püüdsin endale selgeks teha, mis oli V. Ridala mõte seda luues ja jõudsin tulemusele, et ta ehk tahtis kõige eetilisema eluvaate rüütada kõige eetilisemasse vormi - eesti regivärssi. Villem Ridala perekonna ja muidugi ka minu suur soov oli, et poeem ilmuks trükis. Võtsin kohe ühendust kirjastusega Eesti Raamat. Nad tundsid küll huvi, kuid nii mahuka ja vähe tulu tõotava asja kirjastamine oli sel ajal mõeldamatu. Kui Ridala Püha Risti trükkimine nüüd mingi ime läbi teoks peaks saama, siis Veljo Grün- 
thali silmad seda enam kahjuks ei näe, tema lahkus meie hulgast jaanuaris 2002.

Betti Alverit pean meie parimaks naispoeediks. Midagi nii mõttesügavat, kogu maailma suuri muresid haaravat luulet pole keegi teine suutnud luua. Aastate jooksul tegi tema luule läbi palju vormimuutusi. Pärast kuusteist aastat kestnud pausi, mille põhjustas abikaasa Heiti Talviku vangistamine ja surm, tuli ta taas luulesse mõtterikkamana ja täiesti uue vormistusega, mis tugines suuresti regivärsielementidele.

Hando Runnelit austan tema isamaaluule pärast. Nõukogude ajal kergendas tema luule meil kõigil hingamist. Olen kaks korda saanud võimaluse H. Runneli luulest kirjutada. Esimene kord pärast Lauluraamatu (1972) ilmumist. Asta Hameri, tookordne Loomingu toimetaja pakkus retsensiooni jaoks välja süütu aspekti folkloristi pilgu, et siis õnnestub ehk avaldada. Ei õnnestunud! Luulekogu oli küll ilmunud, aga retsensioonid keelati ära. Hiljem, juba uue eesti aja hakul Looming selle siiski avaldas. See avaldamine oli vastuseks kirjandusteadlase Karl Muru arvamusele, nagu poleks Lauluraamatule retsensioone üldse kirjutatud. Teine kord pakuti mulle võimalus kirjutada artikkel $\mathrm{H}$. Runneli juubelikogumikku -jälle folkloristi aspektist. Põdesin parasjagu pikaleveninud grippi ega viitsinud selle folkloristi pilguga eriti vaeva näha, vaid püüdsin lihtsalt välja öelda, kui väga mulle paljud Hando Runneli luuletused meeldivad ja et olen neid lugedes nutnud ja naernud.

Sina ja regilauluseaded helilooja Veljo Tormisele. Millal ja millest algas koostöö? Kadrilauludest? Mardilauludest? Laulumängudest?

Veljo Tormist tunnen palju aastaid ja austan sügavalt tema muusikat. Arvan, et sõna koostöö on liiga suureline - V. Tormis tunneb regilaulu kindlasti paremini kui enamik folkloriste. Alguses muidugi oli ehk ebakindlust ja ta otsis oma mõtetele tuge, tehes koostööd paljude folkloristidega - Herbert Tampere, Olli Kõiva, Ingrid Rüütli, Ülo Tedre ja teistega. Muude läänemeresoome rahvaste laulude puhul tegi ta koostööd ka keeleteadlastega.

Olen märganud, et V. Tormis pöörab palju tähelepanu teksti viimistlusele. Talle on äärmiselt oluline sõna ja teksti avamine kuulajale. Ka selles on ta truuks jäänud regilaulu põhiprintsiibile - kanda sõna abil edasi teadmisi, maailmavaatelisi arusaamu ja eetilisi alustõdesid. Ehk see mõistmine viiski Veljo Tormise koostööle folk- 
loristidega, kes on aidanud tal sõnu sättida. Kuid tekstide sättimine on ikkagi toimunud helilooja juhendite järgi: mida ta on ise tahtnud esile tuua ja mis on paremini sobinud tema muusikalise ideega, see on ka tegelikkuses teostunud.

\section{Kas sinu ettekujutused eesti rahvast ja tema poeetilisest vaimust on aastate jooksul muutunud?}

Regilauludest peale on meil olnud väga palju head luulet, aga ka häid proosateoseid, mis võinuks maailmas laiematki kõlapinda leida, kui olud meile soodsamad oleksid olnud. Eks elu muutub ja poeetiline väljendus muutub koos sellega. Loovast vaimust Eestis puudust pole, kuid mõnele proosaautorile tahaks küll soovitada ropendamisest üle saada.

On ime, et me üldse alles oleme! Kunagi oli Eesti Vabariiki paarkümmend aastat ja minul oli õnn selles lapsena elada. 24. veebruaril, vabariigi aastapäeval, käisime alati sõjaväeparaadi vaatamas. Eriti toredad olid paraadid Viljandis, sest seal paiknes üks Eesti ratsaväe üksus. Ratsaväe mundrid olid eriti uhked, ja kui ilusad ja tulised olid hobused! Meid pandi kodus soojalt riidesse: jalga anti karupüksid ja vildid, suu ette seoti sall. Veebruarikuus oli ju külm. Mäletan, et teel paraadiplatsile möödusime kauplustest, kus vaateaknad olid pidupäevaselt dekoreeritud, lipuvärvides lindid põimitud rohelistest okstest vanikutega. Orkester mängis marssi, meeleolu oli pidulik ja ülev... Ja meie pisikesed jalad püüdsid alati selles marsitaktis sibada.

Vene sõjaväe tulemist 1939. aastal mäletan samuti hästi. Elasin siis Nõmmel Pärnu maantee ääres ja nägin oma noorte erksate silmadega vägede sissetulemist, neid tihedaid-tihedaid, lõputuna tunduvaid tuhmis kortsunud vormis meeste ja sõjamasinate ridu. Mäletan seda õudustunnet, mis mind haaras. Justkui oleks päike kustunud ja maale laskunud tumehall udune pimedus. Mäletan ka kodust meeleolu, vanemate kõnelusi ja lapseohtu noorte omavahelisi jutte ning võin kinnitada, et rahvas oli siis küll valmis võõrale võimule vastu hakkama ja oma eluga vaba riiki kaitsma. Enne baase võinuks ehk veel vastu hakata, pärast võõra sõjaväe sissetoomist polnud selleks enam mingit võimalust. Terve Eesti oli baase täis, mitte ainult rannikualad. Baaside šokile järgnes peagi teine sama jube sündmus - küüditamine. Et midagi niisugust võib üldse juhtuda, oli täiesti arusaamatu ja sisendas kohutavat õudu.

Mida siis rääkida rahvast ja tema iseloomust, kes sai ainult paarkümmend aastat iseseisev olla. Meie rahvuslik iseloom on kujune- 
nud pideva allasurutuse tingimustes. Kaugel eesti ajal kujunenud eestlase autoportree iseloomulikeks joonteks peeti töökust ja ausust. Möödunud viiekümne aasta jooksul kehtis see veel kindlasti välis-Eesti kogukonnas: eestlased töötasid end seal üles, enamik jõudis heale järjele, sest eestlast võis alati ametisse palgata, ta oli töökas ja usaldusväärne.

Missugune on meie nägu nüüd? Soomes ja Rootsis oleme narkodiilerid ja prostitutsiooniärikad, Saksamaal pangaröövlid, Hispaanias mafioosod... Eeltoodu on muidugi liialdus, kuid tõsi on see, et palju loovast energiast, eriti noorte meeste omast, suundub valesti. Veel teeb meele kurvaks rahvusliku üksmeele puudumine ja suutmatus või tahtmatus näha ühiseid, eesti rahvale olulisi asju ja eesmärke. Sellest rääkis omal ajal Jakob Hurt, samast kõnelesid ka Johanes Aavik, August Annist ja veel paljud. Iseennast pean Hurda-meelseks rahvuslaseks ja leian samuti nagu tema, et igal rahval on õigus elada ja edeneda oma vabal maal. 